\title{
REMEDIACJA I STABILIZACJA ZANIECZYSZCZONEGO PODŁOŻA POD ISTNIEJĄCYMI BUDYNKAMI - ANALIZA PRZYPADKU
}

\author{
Ewa Iwanicka ${ }^{1,2} \bowtie$, Sylwia Janiszewska', Eugeniusz Koda ${ }^{2}$ \\ ${ }^{1}$ Menard Polska Sp. z o.o. \\ ${ }^{2}$ Instytut Inżynierii Lądowej, Szkoła Główna Gospodarstwa Wiejskiego w Warszawie
}

\begin{abstract}
STRESZCZENIE
W celu zmniejszenia ilości zanieczyszczeń w trudno dostępnych miejscach, pod istniejącą już zabudową stosuje się często połączone systemy oczyszczania gruntów i/lub wód gruntowych, aby zoptymalizować proces remediacji oraz dostosować metodę do warunków gruntowo-wodnych oraz rodzaju zastanego zanieczyszczenia. Metody oczyszczania gruntów in situ charakteryzują się ponoszeniem mniejszych kosztów w porównaniu do metod ex situ. Oczyszczanie na miejscu stosowane jest przy zanieczyszczeniu dużych powierzchni. Jednakże stosowanie ich pod istniejącą zabudową wiąże się ze zwiększonymi kosztami oczyszczania gruntu. Metody in situ można stosować na terenach zurbanizowanych, przemysłowych czy komunikacyjnych oraz pod obiektami budowlanymi w gęstej zabudowie itp., a nawet gdy w zanieczyszczonej warstwie gruntu występują instalacje infrastrukturalne. Skuteczność remediacji zależy od właściwego doboru metody, którego należy dokonać, uwzględniając ilości i rodzaj zanieczyszczeń występujących na badanym terenie, budowę geologiczną terenu, położenie warstw wodonośnych i kierunek przepływu wód gruntowych. Celem artykułu jest przedstawienie tych metod remediacji gruntów in situ, które ze względu na dużą skuteczność neutralizacji najczęściej spotykanych rodzajów zanieczyszczeń stosuje się pod istniejącą już zabudową i infrastrukturą, tak aby nie naruszyć stateczności obiektu. W artykule przedstawiono dwie metody oczyszczania gruntów in situ, których dobór uwarunkowany był rodzajem substancji zanieczyszczającej zalegającej w gruncie. Podwyższone zawartości w warstwie przypowierzchniowej terenu substancji ropopochodnych zneutralizowano poprzez zastosowanie metody bioremediacji, a w przypadku wykrycia na placu budowy podwyższonych zawartości metali ciężkich w postaci arszeniku zaprojektowano metodę stabilizacji. Dzięki odpowiednio przeprowadzonemu rozpoznaniu terenu przed rozpoczęciem prac, a także prowadzeniu monitoringu przebiegu procesu oczyszczania można było w sposób kontrolowany obserwować zachodzącą neutralizację substancji zanieczyszczających.
\end{abstract}

Słowa kluczowe: remediacja, teren zanieczyszczony, metody in situ

\section{WSTĘP}

Rozwój miast spowodował, iż na terenach dawnych zakładów przemysłowych powstała zabudowa mieszkalna i budynki użyteczności. Tereny te są często atrakcyjne ze względu na ich lokalizację w ścisłym centrum miasta, jednak jakość gruntów w podłożu zastana po poprzednim użytkowaniu może być zaburzona poprzez zawartość nadmiernych stężeń związków szkodliwych dla zdrowia człowieka i środowiska wodno-gruntowego oraz dla parametrów geotechnicznych. Grunty na tych obszarach zanieczyszczone są głównie metalami ciężkimi oraz substancjami ropopochodnymi, takimi jak: frakcje benzyn i frakcje oleju napędowego, chlorowane rozpuszczalniki, fenole, węglowodory aromatyczne oraz wielopierścieniowe węglowodory 
aromatyczne. Zarówno dawniej, jak i obecnie nie ma prawnego obowiązku wykonywania badań pod kątem występowania skażonego gruntu.

Od 2001 roku wprowadzono obowiązek wykonywania oczyszczania gruntu zanieczyszczonego, czyli przeprowadzenia procesu remediacji, jeżeli takie zanieczyszczenie zostało potwierdzone badaniami. Prawo ochrony środowiska z 2001 roku definiuje pojęcie remediacji jako „poddanie gleby, ziemi i wód gruntowych działaniom mającym na celu usunięcie lub zmniejszenie ilości substancji powodującej ryzyko, ich kontrolowanie oraz ograniczanie rozprzestrzeniania się, tak aby teren zanieczyszczony przestał stwarzać zagrożenie dla zdrowia ludzi lub stanu środowiska, z uwzględnieniem obecnego i o ile jest to możliwe, planowanego w przyszłości sposobu użytkowania terenu". Ponadto ustawa ta zawierała informacje, iż remediacja może polegać również na samooczyszczaniu, które rozumie się jako „biologiczne, chemiczne i fizyczne procesy, których skutkiem jest ograniczenie ilości, ładunku, stężenia, toksyczności, dostępności oraz rozprzestrzeniania się zanieczyszczeń w glebie, ziemi i wodach, przebiegające samoistnie, bez ingerencji człowieka, ale których przebieg może być przez człowieka wspomagany". Kolejnym aktem prawnym, który reguluje zagadnienia rekultywacji, jest ustawa z 2007 roku o zapobieganiu szkodom w środowisku i ich naprawie. Jeżeli w myśl cytowanych ustaw zawartość szkodliwych substancji występujących w gruncie przekracza standardy jakości gleb i ziemi według rozporządzenia Ministra Środowiska z 2016 roku, grunt należy poddać zabiegom oczyszczania w celu usunięcia ich ponadnormatywnych ilości (Karczewska i Kabała, 2010). W przypadku udokumentowania skażenia oczyszczanie gruntu jest obligatoryjne i spoczywa na władającym powierzchnią terenu. W przypadku ujawnienia $\mathrm{w}$ gruncie jakichkolwiek szkodliwych substancji obowiązek ich usunięcia, a więc także związane z tym koszty rekultywacji ponosi właściciel posesji. $\mathrm{W}$ rozporządzeniu tym podstawowe zanieczyszczenia podzielono na grupy stanowiące: metale i metaloidy; zanieczyszczenia nieorganiczne; węglowodory (benzyny i oleje, węglowodory aromatyczne i wielopierścieniowe węglowodory aromatyczne); węglowodory chlorowane; środki ochrony roślin (pestycydy chloroorganiczne i pestycydy - związki niechlorowe) oraz pozostałe zanieczyszczenia. Zbiór substancji powodujących ryzyko środowiska stanowi listę otwartą, bowiem wymieniono $\mathrm{w}$ niej najczęściej występujące związki chemiczne pochodzące z przemysłu (US Environmental Protection Agency, 1995). Każdy zanieczyszczony teren wymaga indywidualnej analizy (Koda i Osiński, 2016) oraz dobrania odpowiedniej metody działania naprawczego, czyli przeprowadzania procesu remediacji. Wykonanie oczyszczania zanieczyszczonego gruntu pod istniejąca już infrastrukturą możliwe jest przy zastosowaniu metod in situ. Zastosowanie metod in situ umożliwia rozwiązanie problemu rekultywacji na miejscu, bowiem metody te nie prowadza do powstawania nowych składowisk odpadów ani dodatkowego zanieczyszczenia środowiska w wyniku transportu gruntów zanieczyszczonych na składowisko. Omawiane metody znajdują zastosowanie na terenach zurbanizowanych, przemysłowych, pod budynkami, w ścisłej zabudowie czy pod drogami. Polegają na oczyszczaniu gruntów i wód gruntowych bez konieczności prowadzenia złożonych prac ziemnych (metoda ex situ) oraz wywozu znacznych ilości skażonego gruntu, a także jego późniejszej utylizacji.

Stosowane metody remediacji gruntów można podzielić na: fizyczne, chemiczne, termiczne i biologiczne (Sax, Bassuk, van Es i Rakow, 2017). Do metod fizycznych zaliczamy ekstrakcję i sortowanie, wśród metod chemicznych wyróżniamy: odmywanie, dehalogenację, ekstrakcję, hydrolizę, utlenianie-redukcję i stabilizację (sorpcję, regulację $\mathrm{pH}$ ), do metod termicznych zaliczamy: desorpcję termiczną, zeszklanie i spalanie, a wśród metod biologicznych stosujemy bioremediację i fitoremediację (Wang, Feng, Anderson, Xing i Shang, 2012; Xu i in., 2015). Przed rozpoczęciem prowadzenia procesu remediacji pod istniejącą zabudową należy przeprowadzić szczegółową analizę ryzyka. Zgodnie z założeniem celu remediacji należy uwzględnić zagrożenia, jakie niosą dla środowiska naturalnego i zdrowia człowieka substancje szkodliwe rozpuszczone w wodzie, które mogą stanowić źródło zanieczyszczenia. Dyrektywa 2000/60/WE oraz dyrektywa 2006/118/WE określają, że konieczność podejmowania prac remediacyjnych wynika z zachowania zasady proporcjonalności, która polega na dobraniu optymalnej metody pozwalającej na osiągnięcie wyznaczonego efektu 
w stosunku do poniesionych kosztów (Kruszyńska, Saloni, Janiszewska i Koda, 2018).

\section{METODY}

\section{Stabilizacja}

Zestalanie i stabilizacja, inaczej solidyfikacja, jest jednym ze sposobów fizykochemicznego zmniejszania mobilności substancji niebezpiecznych $\mathrm{w}$ gruncie. Zazwyczaj jest ona stosowana do gruntów zanieczyszczonych metalami ciężkimi i innymi substancjami nieorganicznymi. W procesie stabilizacji zmniejsza sie ryzyko związane z migracją zanieczyszczeń poprzez chemiczne przekształcenie substancji zanieczyszczających w mniej rozpuszczalne, immobilizowane i tym samym mniej toksyczne, a także poprzez zmianę niektórych parametrów fizycznych, aby uzyskać np. poprawę wytrzymałości mechanicznej, zmniejszenie nasiąkliwości, zwiększenie mrozoodporności itp. (Sorengard, Berggren, i Ahrens, 2019). Wykonywanie stabilizacji powiązane jest równocześnie z projekto- waniem fundamentów bezpośrednich, które polega na sprawdzeniu stanów granicznych nośności (ULS) i użytkowalności (SLS). Jeśli w poziomie posadowienia osiągnięta zostanie graniczna wartość naprężenia, wówczas nie będzie już możliwy dalszy wzrost obciążenia, a w konsekwencji utrata nośności podłoża. Osiągnięcie granicznej wartości nierównomiernego bądź nadmiernego przemieszczenia konstrukcji spowodowanego osiadaniem podłoża jest nazywane stanem granicznym użytkowalności (Osiński, Nowakowska, Jeleniewicz, Dohojda i Koda, 2018).

Procesowi stabilizacji poddaje się najczęściej odpady szkodliwe o charakterze nieorganicznym lub takie, które zawierają niewielkie ilości związków organicznych, z jakich mogą być wymywane rozpuszczalne związki chemiczne metali, stanowiące substancje potencjalnie zagrażające środowisku naturalnemu. Zabieg polega na ciśnieniowym wprowadzaniu do gruntu iniektu stabilizującego metale ciężkie przy równoczesnym mieszaniu gruntu (rys. 1). Odpad po stabilizacji można wykorzystać jako kruszywo drogo-

Rys. 1. Schemat procesu stabilizacji zanieczyszczonego gruntu w podłożu

Fig. 1. Diagram of the subsoil stabilization process

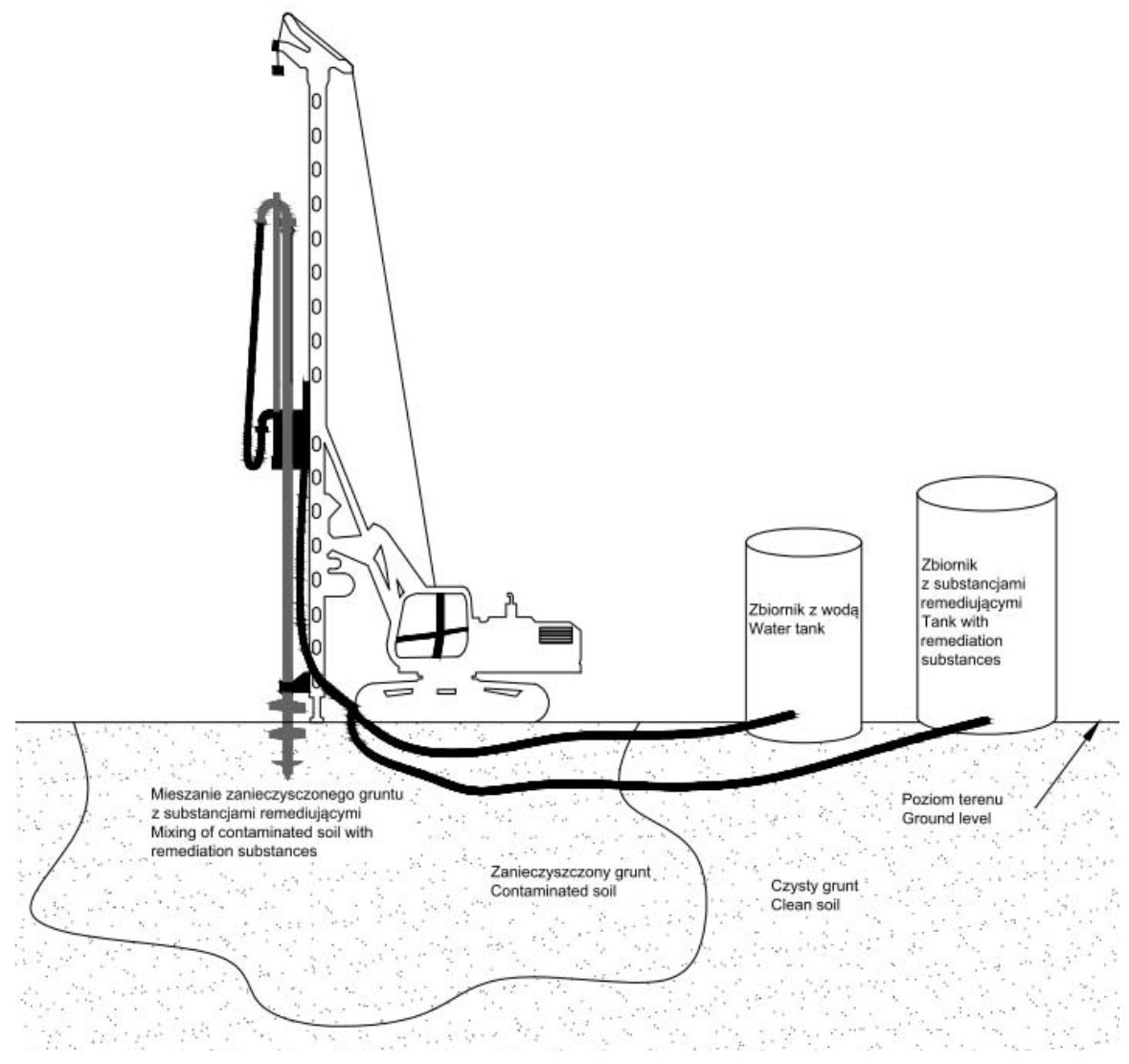


we, kruszywo do budownictwa przemysłowego lub do robót inżynieryjnych.

\section{Bioremediacja grawitacyjna}

Technologia usuwania zanieczyszczeń głównie substancji ropopochodnych $\mathrm{z}$ zanieczyszczonych gleb i gruntów. Powierzchniowe grawitacyjne zraszanie gruntu wodnym roztworem substancji biogennych stosuje się w przypadku płytkiego (do ok. $5 \mathrm{~m}$ ) zanieczyszczenia podłoża gruntowego. Techniki bioremediacyjne wykorzystują naturalny potencjał mikroorganizmów do degradacji zanieczyszczeń organicznych. Mikroorganizmy mają wykształconą w drodze ewolucji zdolność do rozkładu niemal wszystkich naturalnych związków organicznych występujących w przyrodzie (Pawlik, 2018). Roztwór dodatkowo może zawierać mikroorganizmy, które mają za zadanie obniżenie stężenia zanieczyszczeń do poziomu niezagrażającego zdrowiu ludzi i stanu środowiska. Mikroorganizmy przekształcają substancje ropopochodne do związków prostych, czyli wody i dwutlenku węgla. Przy głębszym zanieczyszczeniu bardziej odpowiednie jest podpowierzchniowe grawitacyjne rozprowadzenie roztworu biogenów za pomoca galerii infiltracyjnych oraz złóż filtracyjnych (rys. 2).
W procesie bioremediacji dodatkowo kontrolowany jest poziom tlenu oraz wilgotność podłoża $\mathrm{w}$ celu sterowania przebiegu tego procesu. Na tempo procesu bioremediacji mają wpływ, oprócz składu chemicznego związków zanieczyszczających grunt, ich stężenia oraz mikrobiologiczny potencjał gruntu, fizykochemiczne parametry środowiska i dostępność węglowodorów dla komórek mikroorganizmów (Hejazi, 2002). Na proces biodegradacji niekorzystnie wpływa spadek temperatury, który spowalnia rozwój drobnoustrojów. Pożądaną temperaturą podczas prowadzenia bioremediacji jest $25-40^{\circ} \mathrm{C}$, a optymalna wilgotność gruntu wynosi ok. $18 \%$.

\section{WYNIKI}

\section{Solidyfikacja (stabilizacja) - studium przypadku}

Stabilizacja, inaczej zwana metodą solidyfikacji, ma na celu zmniejszenie mobilności substancji niebezpiecznych w gruncie (Sherwood i Qualls, 2001). Metoda ta stosowana jest głównie do gruntów zanieczyszczonych metalami ciężkimi i innymi substancjami nieorganicznymi. $\mathrm{W}$ tym procesie następuje zmniejszenie ryzyka, które związane jest z migracją zanieczyszczeń poprzez przekształcenie substancji zanieczyszczają-

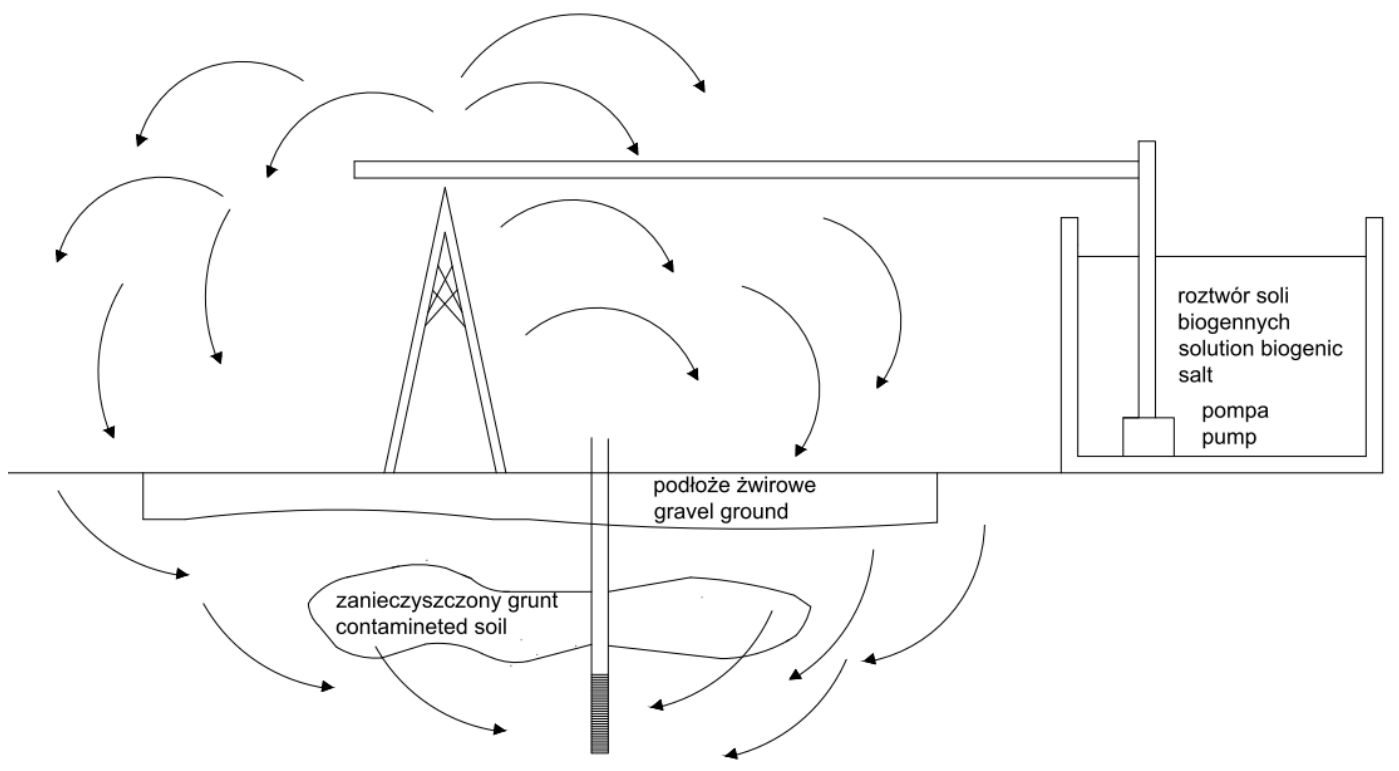

Rys. 2. Schemat procesu bioremediacji gruntu

Fig. 2. Diagram of the soil bioremediation process 
Iwanicka, E., Janiszewska, S., Koda, E. (2020). Remediacja i stabilizacja zanieczyszczonego podłoża pod istniejącymi budynkami - analiza przypadku. Acta Sci. Pol. Architectura, 19 (1), 63-71. doi: 10.22630/ASPA.2020.19.1.7

cych w mniej rozpuszczalne, immobilizowane i tym samym mniej toksyczne (Suthersan, 1997; Anderson i Mitchell, 2003).

Remediacja w analizowanym przypadku polegała na zastosowaniu procesu stabilizacji, która miała ograniczyć migrację zanieczyszczeń $\mathrm{z}$ wodami gruntowymi. Przedmiotowy grunt był zanieczyszczony arszenikiem, który niegdyś składowano pod powierzchnią terenu. Zwierciadło wód podziemnych odnotowano na głębokości ok. $6 \mathrm{~m}$ p.p.t. Na przedmiotowej działce znajdował się budynek wraz $\mathrm{z}$ drogą dojazdową. Budowle te miały być zachowane w sposób nienaruszony ze względu na planowaną nową inwestycję. Remediację gruntu przeprowadzono $\mathrm{w}$ strefie infiltracji (0-5 m p.p.t.) i w strefie nasycenia wód (5-8 m p.p.t.). Dodatek reagenta spowodował przekształcenie formy arszeniku w formę nierozpuszczalną (arsenian żelaza). Nastapiła immobilizacja zanieczyszczenia. Prace prowadzono do głębokości $8 \mathrm{~m}$ p.p.t., na terenie o powierzchni ok. $3000 \mathrm{~m}^{2}$. Objętość gruntu poddanego remediacji wyniosła $16048 \mathrm{~m}^{3}$. Prace przygotowawcze polegały na wyznaczeniu i wykonaniu siatki punktów iniekcyjnych w rozstawie 1,5 do 3 m (rys. 3). Następnie odwiercono $w$ gruncie otwory i przeprowadzono iniekcję roztworu mobilizującego arszenik. Skład reagenta użytego do immobilizacji arszeniku opracowano i stworzono w laboratorium na podstawie składu chemicznego uprzednio pobranych próbek gruntu. Wykonanie testu pilotażowego umożliwiło określenie dokładnych parametrów iniekcji, do których należą tempo przepływu oraz docelowa objętość preparatu iniekcyjnego. Na placu budowy stworzono terenowy system produkujący roztwór iniekcyjny (rys. 3B). Proces iniekcji prowadzono przez dwa miesięce za pomocą siedmiu perystaltycznych pomp iniekcyjnych o jednostkowej wydajności $1,2 \mathrm{~m}^{3} \cdot \mathrm{h}^{-1}$. Po przeprowadzeniu procesu remediacji w celu potwierdzenia skuteczności wykonywanych prac przeprowadzono testy odbiorcze odcieków, które wykazały uzyskanie 96-procentowej redukcji zanieczyszczenia.

\section{Bioremediacja grawitacyjna - studium przypadku}

Procesowi remediacji metodą bioremediacji grawitacyjnej poddano przedmiotowy teren zgodnie $\mathrm{z}$ wydaną decyzja remediacyjna. Teren objęty pracami naprawczymi obejmował obszar o powierzchni ok. 12332 $\mathrm{m}^{2}$, głębokość zalegania gruntów zanieczyszczonych obejmowała strefe przypowierzchniowa $0-0,25 \mathrm{~m}$ p.p.t. Substancjami niebezpiecznymi występującymi w gruncie i podlegającymi procesowi remediacji była suma weglowodorów $\mathrm{C}_{12}-\mathrm{C}_{35}$. Wystepowanie na przedmiotowym terenie zanieczyszczeń olejów spowodowane było prowadzoną działalnością

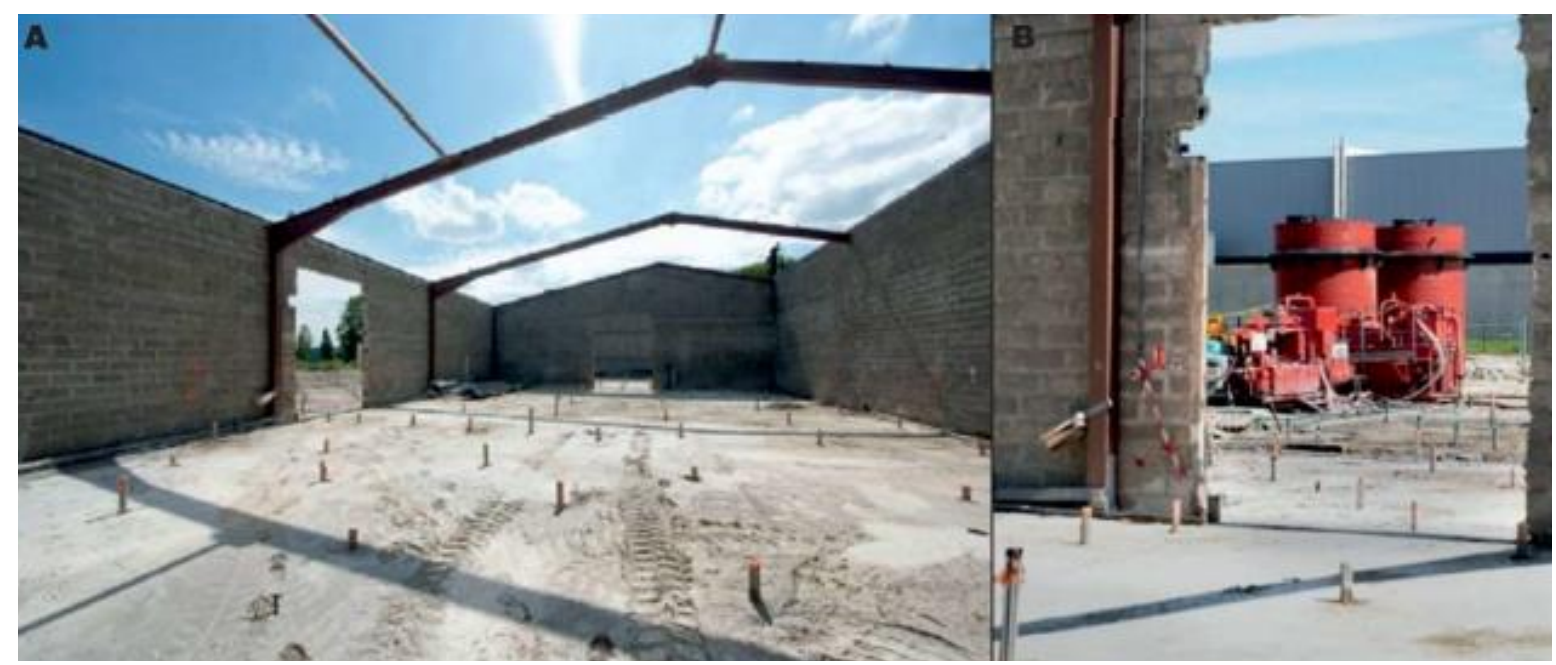

Rys. 3. Stabilizacja gruntu na analizowanym obiekcie: A - siatka punktów iniekcyjnych; B - jednostka produkująca reagent (fot. Menard)

Fig. 3. Soil stabilization on analysed site: A - grid of injection points; B - reagent production unit (photo by Menard) 
Iwanicka, E., Janiszewska, S., Koda, E. (2020). Remediacja i stabilizacja zanieczyszczonego podłoża pod istniejącymi budynkami - analiza przypadku. Acta Sci. Pol. Architectura, 19 (1), 63-71. doi: 10.22630/ASPA.2020.19.1.7

rolniczą, transportem urządzeń i wyciekami oleju z nieszczelnych zbiorników. Początkowe poziomy zanieczyszczenia gruntu w sekcjach zanieczyszczonych przedstawiono w tabeli 1 . Na podstawie otrzymanych wyników badań wstępnych oszacowano ilość bioroztworu niezbędna do przeprowadzenia procesu oczyszczania. Założeniem było prowadzenie prac przez trzy miesiące.

Wykonanie prac remediacyjnych rozpoczęto od prowadzenia pierwszej serii zraszania gruntu na sekcjach zanieczyszczonych (2, 3, 4 i 6 - rys. 4$)$ bioroztworem bakterii zdolnych do oczyszczania gruntu zanieczyszczonego substancjami ropopochodnymi.
Preparat rozcieńczono w zbiorniku typu mauzer zamontowanym na atestowanym opryskiwaczu. Po trzech tygodniach od przeprowadzenia pierwszej serii zraszania gruntu dokonano poboru kontrolnych próbek gruntu. Termin poboru próbek przyspieszono $\mathrm{z}$ uwagi na spadek temperatury otoczenia, związany ze zmianą warunków atmosferycznych, które mają istotny wpływ na przebieg prowadzonego procesu (Weyens, van der Lelie, Taghavi, Newman i Vangronsveld, 2009; Saleem, 2016). Pobrano cztery zbiorcze próbki gruntu, po jednej próbce z każdej zanieczyszczonej sekcji. Każda pojedyncza przesłana do laboratorium próbka zbiorcza składała się z piętnastu próbek

Tabela 1. Wykaz substancji niebezpiecznych oznaczonych $\mathrm{w}$ gruncie na omawianym terenie

Table 1. List of hazardous substances marked in the subsoil in the analyzed area

\begin{tabular}{|c|c|c|c|c|c|}
\hline $\begin{array}{l}\text { Wskaźnik } \\
\text { Indicator }\end{array}$ & $\begin{array}{l}\text { Grupa gruntów I } \\
\text { (głębokość } 0-0,25 \mathrm{~m} \text { ) } \\
\text { Group of soil I } \\
\text { (depth } 0-0.25 \mathrm{~m}) \\
{\left[\mathrm{mg} \cdot \mathrm{kg}^{-1} \mathrm{sm}\right]}\end{array}$ & $\begin{array}{c}\text { Sekcja } 2 \\
\text { Section } 2 \\
{\left[\mathrm{mg} \cdot \mathrm{kg}^{-1} \mathrm{sm}\right]}\end{array}$ & $\begin{array}{c}\text { Sekcja } 3 \\
\text { Section } 3 \\
{\left[\mathrm{mg} \cdot \mathrm{kg}^{-1} \mathrm{sm}\right]}\end{array}$ & $\begin{array}{c}\text { Sekcja } 4 \\
\text { Section } 4 \\
{\left[\mathrm{mg} \cdot \mathrm{kg}^{-1} \mathrm{sm}\right]}\end{array}$ & $\begin{array}{c}\text { Sekcja } 6 \\
\text { Section } 6 \\
{\left[\mathrm{mg} \cdot \mathrm{kg}^{-1} \mathrm{sm}\right]}\end{array}$ \\
\hline $\begin{array}{l}\text { Olej mineralny } \mathrm{C}_{12}-\mathrm{C}_{35} \\
\text { TPH } \mathrm{C}_{12}-\mathrm{C}_{35}\end{array}$ & 30 & 54 & 210 & 35 & 41 \\
\hline
\end{tabular}

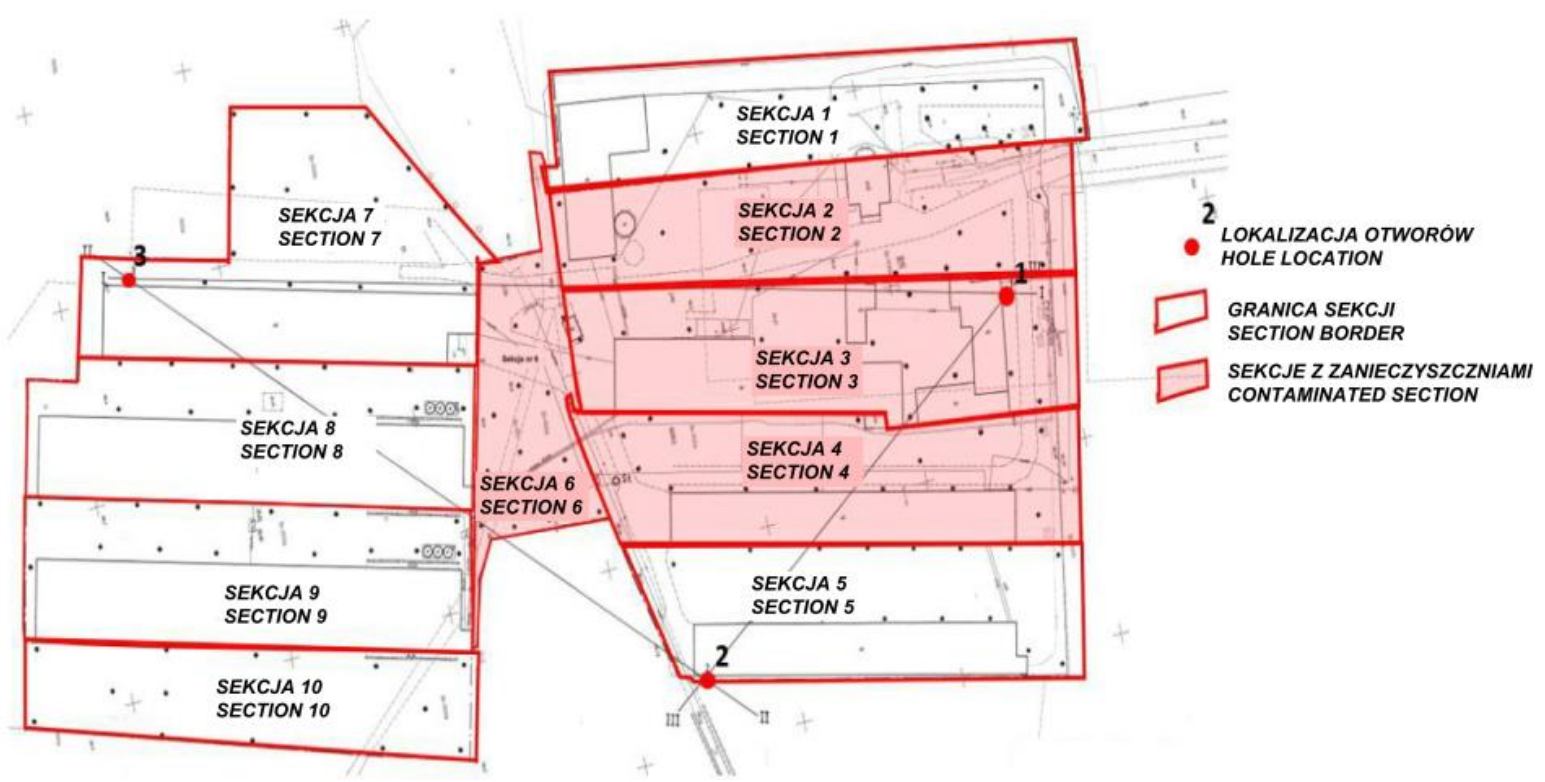

Rys. 4. Mapa podziału terenu na sekcje (fot. Menard)

Fig. 4. Map with the division of the site into sections (photo by Menard) 
Iwanicka, E., Janiszewska, S., Koda, E. (2020). Remediacja i stabilizacja zanieczyszczonego podłoża pod istniejącymi budynkami - analiza przypadku. Acta Sci. Pol. Architectura, 19 (1), 63-71. doi: 10.22630/ASPA.2020.19.1.7

pojedynczych pobieranych $\mathrm{z}$ głębokości $0-0,25 \mathrm{~m}$ p.p.t. Próbki pobierano świdrem ręcznym, następnie umieszczano je w czystych słoikach dostarczonych przez laboratorium.

Analizując wyniki otrzymanych analiz laboratoryjnych po przeprowadzeniu pierwszej serii badań przedstawionych w tabeli 2, odnotowano spadek stężeń substancji oleju w każdej z czterech oczyszczanych sekcji badawczych. Całkowitemu oczyszczeniu uległa sekcja badawcza 4. Obszar ten nie wymagał dużej ingerencji ze względu na niewielkie odnotowane przekroczenia limitów. Zawartość frakcji oleju w pozostałych sekcjach spadła, nie mniej jednak nie można było na tym etapie zakończyć procesu oczyszczania ze względu na występujące przekroczenie dopuszczalnych standardów jakości (limitów dopuszczalnych).

Kontynuując proces oczyszczania metoda bioremediacji grawitacyjnej, przystapiono do wykonania drugiej serii zraszania gruntu $\mathrm{w}$ zanieczyszczonych sekcjach (2, 3, 4 i 6 - rys. 4) bioroztworem bakterii zdolnych do oczyszczania środowiska gruntowego z zanieczyszczeń ropopochodnych. Poboru drugiej serii kontrolnych próbek gruntu dokonano po miesiącu od wykonania drugiej serii zraszania powierzchni gruntu. Analogicznie do poprzedniej serii pobrano cztery zbiorcze próbki gruntu, po jednej próbce zbiorczej na sekcję zanieczyszczoną. Na próbkę zbiorczą składało się piętnaście próbek pojedynczych. Wyniki przeprowadzonych analiz laboratoryjnych przedstawiono w tabeli 3.

Zanieczyszczony grunt, poddany procesowi oczyszczania metoda bioremediacji grawitacyjnej in situ, doprowadzono do standardów jakości I grupy gruntów zgodnie z rozporządzeniem Ministra Środowiska z 2016 roku odnośnie metod oceny zanieczyszczenia powierzchni ziemi. Istotą działań remediacyjnych w prowadzonym procesie jest kontrolowanie przebiegu prac poprzez cykliczne prowadzenie analiz laboratoryjnych pobranych próbek gruntu pochodzących z terenu poddanego oczyszczaniu, a także odpowiednie wsadowe do zaprojektowania procesu prowadzenia prac. Nieznaczna głębokość występowania zanieczyszczeń (maks. 0,25 m), rodzaje gruntów (niespoiste), a także niewielkie przekroczenia

Tabela 2. Wykaz substancji niebezpiecznych oznaczonych $\mathrm{w}$ gruncie na omawianym terenie

Table 2. List of substances marked in the subsoil in the analyzed area

\begin{tabular}{|c|c|c|c|c|c|}
\hline $\begin{array}{l}\text { Wskaźnik } \\
\text { Indicator }\end{array}$ & $\begin{array}{c}\text { Grupa gruntów I } \\
\text { (głębokość } 0-0,25 \mathrm{~m} \text { ) } \\
\text { Group of soil I } \\
(\text { depth } 0-0.25 \mathrm{~m}) \\
{\left[\mathrm{mg} \cdot \mathrm{kg}^{-1} \mathrm{sm}\right]}\end{array}$ & $\begin{array}{c}\text { Sekcja } 2 \\
\text { Section } 2 \\
{\left[\mathrm{mg} \cdot \mathrm{kg}^{-1} \mathrm{sm}\right]}\end{array}$ & $\begin{array}{c}\text { Sekcja } 3 \\
\text { Section } 3 \\
{\left[\mathrm{mg} \cdot \mathrm{kg}^{-1} \mathrm{sm}\right]}\end{array}$ & $\begin{array}{c}\text { Sekcja } 4 \\
\text { Section } 4 \\
{\left[\mathrm{mg} \cdot \mathrm{kg}^{-1} \mathrm{sm}\right]}\end{array}$ & $\begin{array}{c}\text { Sekcja } 6 \\
\text { Section } 6 \\
{\left[\mathrm{mg} \cdot \mathrm{kg}^{-1} \mathrm{sm}\right]}\end{array}$ \\
\hline $\begin{array}{l}\text { Olej mineralny } \mathrm{C}_{12}-\mathrm{C}_{35} \\
\text { TPH C }_{12}-\mathrm{C}_{35}\end{array}$ & 30 & 53,1 & 58,8 & $<30^{*}$ & 40,4 \\
\hline
\end{tabular}

* Granica oznaczalności stosowanej aparatury badawczej - Limit of quantificationof the test apparatus used.

Tabela 3. Wykaz substancji niebezpiecznych oznaczonych w gruncie na omawianym terenie

Table 3. List of hazardous substances marked in the subsoil in the analyzed area

\begin{tabular}{|c|c|c|c|c|c|}
\hline $\begin{array}{l}\text { Wskaźnik } \\
\text { Indicator }\end{array}$ & $\begin{array}{c}\text { Grupa gruntów I } \\
\text { (głębokość } 0-0,25 \mathrm{~m} \text { ) } \\
\text { Group of soil I } \\
\text { (depth } 0-0.25 \mathrm{~m} \text { ) } \\
{\left[\mathrm{mg} \cdot \mathrm{kg}^{-1} \mathrm{sm}\right]}\end{array}$ & $\begin{array}{c}\text { Sekcja } 2 \\
\text { Section } 2 \\
{\left[\mathrm{mg} \cdot \mathrm{kg}^{-1} \mathrm{sm}\right]}\end{array}$ & $\begin{array}{c}\text { Sekcja } 3 \\
\text { Section } 3 \\
{\left[\mathrm{mg} \cdot \mathrm{kg}^{-1} \mathrm{sm}\right]}\end{array}$ & $\begin{array}{c}\text { Sekcja } 4 \\
\text { Section } 4 \\
{\left[\mathrm{mg} \cdot \mathrm{kg}^{-1} \mathrm{sm}\right]}\end{array}$ & $\begin{array}{c}\text { Sekcja } 6 \\
\text { Section } 6 \\
{\left[\mathrm{mg} \cdot \mathrm{kg}^{-1} \mathrm{sm}\right]}\end{array}$ \\
\hline $\begin{array}{l}\text { Olej mineralny } \mathrm{C}_{12}-\mathrm{C}_{35} \\
\text { TPH } \mathrm{C}_{12}-\mathrm{C}_{35}\end{array}$ & 30 & $<30^{*}$ & $<30^{*}$ & $<30^{*}$ & $<30^{*}$ \\
\hline
\end{tabular}

${ }^{*}$ Granica oznaczalności stosowanej aparatury badawczej - Limit of quantification of the test apparatus used. 
Iwanicka, E., Janiszewska, S., Koda, E. (2020). Remediacja i stabilizacja zanieczyszczonego podłoża pod istniejącymi budynkami - analiza przypadku. Acta Sci. Pol. Architectura, 19 (1), 63-71. doi: 10.22630/ASPA.2020.19.1.7

dopuszczalnych zawartości pozwoliły przeprowadzić proces oczyszczania w stosunkowo krótkim czasie z użyciem niewielkich nakładów finansowych, którymi odznaczają się metody in situ. Zakładane efekty oczyszczania uzyskano dzięki sprzyjającym warunkom gruntowym (występowanie piasków) i prawidłowemu dobraniu metody.

\section{WNIOSKI}

$\mathrm{W}$ artykule przedstawiono dwa przykłady realizacji procesu oczyszczania terenu przy wykorzystaniu technologii wykonywania prac in situ bez konieczności wywozu zanieczyszczonego gruntu poza teren inwestycji. Zastosowanie metody stabilizacji niesie ze sobą korzyść przy projektowaniu posadowienia obiektu poprzez poprawę warunków mechanicznych podłoża budowlanego, tak aby spełnione były warunki geotechniczne posadowienia obiektu określone przez Eurokod 7 wraz z jednoczesną immobilizacją zanieczyszczeń nieorganicznych. Metoda bioremediacji grawitacyjnej jest metoda przyjazna środowisku, nie prowadzi do powstawania wykopów budowlanych i może być stosowana bez potrzeby ingerencji w znajdujące się na tym terenie obiekty budowalne. Dzięki przeprowadzonym analizom badawczym dowiedziono, że czas stosowanej bioremediacji uzależniony jest od ilości substancji zanieczyszczającej, przekraczającej dopuszczalne normy w gruncie, a także od głębokości jej zalegania. Dozowanie odpowiednich preparatów w określonych odstępach czasowych doprowadzi do całkowitego usunięcia zanieczyszczeń ropopochodnych z gruntu. Przy ocenie stanu jakości gruntów i późniejszym planowaniu naprawy jakości środowiska należy brać pod uwagę możliwość kombinacji metod, tak aby proces oczyszczania był korzystny zarówno dla inwestora, jak i środowiska. Poszukiwanie alternatywnych metod oczyszczania terenu stanowi wyzwanie dla projektantów, którzy zrównoważonym projektowaniem mogą połączyć proces remediacji z procesem geotechnicznego wzmocnienia podłoża przy wykorzystaniu metody stabilizacji. Skuteczność zaprojektowanej metody remediacji należy analizować poprzez odpowiednio zaprojektowany plan badawczy, który dla każdej metody należy rozpatrywać oddzielnie w zależności od przyjętej tech- nologii, warunków wodno-gruntowych oraz rodzaju zanieczyszczenia, jakie należy zneutralizować.

\section{PIŚMIENNICTWO}

Anderson, A. i Mitchell P. (2003). Treatment of mercury-contaminated soil, mine waste and sludge using silica micro-encapsulation. W M.E. Schlesinger (red.) Extraction and Processing Division. 2003 EPD congress (strony 265-274). San Diego: Minerals, Metals \& Materials Society.

Dyrektywa 2000/60/WE Parlamentu Europejskiego i Rady z dnia 23 października 2000 r. ustanawiająca ramy wspólnotowego działania w dziedzinie polityki wodnej. Dz.U. L 327 z 22.12.2000.

Dyrektywa 2006/118/WE Parlamentu Europejskiego i Rady z dnia 12 grudnia 2006 r. w sprawie ochrony wód podziemnych przed zanieczyszczeniem i pogorszeniem ich stanu. Dz.U. L 372 z 27.12.2006.

Hejazi, R. F. (2002). Oily Sludge Degradation Study under Arid Conditions Using a Combination of Landfarm and Bioreactor Technologies (rozprawa doktorska). Memorial University of Newfoundland, St. John's.

Karczewska, A. i Kabała, C. (2010). Gleby zanieczyszczone metalami ciężkimi i arsenem na Dolnym Śląsku - potrzeby i metody rekultywacji. Zeszyty Naukowe Uniwersytetu Przyrodniczego we Wroclawiu. Rolnictwo, 576, 59-79.

Koda, E. i Osiński, P. (2016). Site Investigation of an Industrial Landfill for the Purpose of a Remedial Works Project. Proceedings of Geo-Chicago 2016. ASCE Geotechnical Special Publication, 273, 750-757.

Kruszyńska, E., Saloni, J., Janiszewska, S. i Koda, E. (2018). Badania geośrodowiskowe terenów poprzemysłowych na potrzeby rekultywacji i projektów zagospodarowania. Inżynieria Morska i Geotechnika, 4, 302-305.

Osiński, P., Nowakowska, E., Jeleniewicz, K., Dohojda, M. i Koda, E. (2018). Analiza wpływu jakości rozpoznania podłoża gruntowego na ocenę stanu granicznego nośności i użytkowalności na przykładzie wybranego obiektu. Acta Sci. Pol. Architectura, 17 (3), 47-55. doi: 10.22630/ASPA.2018.17.3.28

Pawlik, M. (2018). Rola bakterii endofitycznych w fitoremediacji gleb skażonych zwiazkami ropopochodnymi (praca doktorska). Uniwersytet Śląski, Katowice.

PN-EN 1997-1. Eurokod 7. Projektowanie geotechniczne. Część 1: Zasady ogólne.

Rozporządzenie Ministra Środowiska z dnia 1 września 2016 roku w sprawie sposobu prowadzenia oceny zanieczyszczenia powierzchni ziemi. Dz.U. 2016, poz. 1395. 
Iwanicka, E., Janiszewska, S., Koda, E. (2020). Remediacja i stabilizacja zanieczyszczonego podłoża pod istniejącymi budynkami - analiza przypadku. Acta Sci. Pol. Architectura, 19 (1), 63-71. doi: 10.22630/ASPA.2020.19.1.7

Saleem, H. (2016). Plant-bacteria partnership: phytoremediation of hydrocarbons contaminated soil and expression of catabolic genes. Bulletin of Environmental Studies, 1, $18-28$.

Sax, S. M., Bassuk, N., Es, H. van i Rakow, D. (2017). Longterm remediation of compacted urban soils by physical fracturing and incorporation of compost. Urban Forestry \& Urban Greening, 24, 149-156.

Sherwood, L. J. i Qualls, R. G. (2001). Stability of phosphorus within a wetland soil following ferric chloride treatment to control eutrophication. Environmental Science and Technology, 35 (20), 4126-4131.

Sorengard, M., Berggren Kleja, D. i Ahrens, L. (2019). Stabilization and solidification remediation of soil contaminated with poly-and perfluoroalkyl substances (PFASs). Journal of Hazardous Materials, 367, 639-646.

Suthersan, S. S. (1997). Remediation Engineering: Design Concepts. Boca Raton: Lewis Publishers.

US Environmental Protection Agency (1995). How to Evaluate Alternative Cleanup Technologies for Underground Storage Tank Sites. A Guide for Corrective Action Plan
Reviewers. Chapter V. Landfarming. Publication EPA 510-B-95-007. Office of the Underground Storage Tank. Washington, DC. Pobrane z: https://www.epa.gov/sites/ production/files/2014-03/documents/tum_ch5.pdf

Ustawa z dnia 13 kwietnia 2007 r. o zapobieganiu szkodom w środowisku i ich naprawie. Dz.U. 2007, poz. 493.

Ustawa z dnia 27 kwietnia 2001 r. Prawo ochrony środowiska. Dz.U. 2001, poz. 627.

Wang, J., Feng, X., Anderson, C. W. N., Xing, Y. i Shang, L. (2012). Remediation of mercury contaminated sites - A review. Journal of Hazardous Materials, 221-222, 1-18. doi: 10.1016/j.jhazmat.2012.04.035

Weyens, N., Lelie, D.van der, Taghavi, S., Newman, L. i Vangronsveld, J. (2009). Exploiting plant-microbe partnerships for improving biomass production and remediation. Trends in Biotechnology, 27 (10), 591-598. doi: 10.1016/j.tibtech.2009.07.006

Xu, J., Bravo, A. G., Lagerkvist, A., Bertilsson, S., Sjöblomb, R. i Kumpiene, J. (2014). Sources and remediation techniques for mercury contaminated soil. Environment International, 74, 42-53. doi: 10.1016/j.envint.2014.09.007

\title{
REMEDIATION AND STABILIZATION OF CONTAMINATED SUBSOIL UNDER EXISTING BUILDINGS - CASE STUDY
}

\begin{abstract}
In order to reduce the amount of impurities in the ground under the existing buildings, the combined use of purification system of ground and ground water remediation process allow optimization depending on the type of soil and water and the type of contamination. In-situ soil treatment methods are characterized by low costs and are particularly useful for cleaning large surfaces. However, applying them under the existing buildings entails increased costs of soil purification. In-situ soil treatment methods can be applied in urbanized or industrial areas, under building constructions, in the nearby development or under roads, etc., even when there are infrastructure installations in the contaminated ground layers. The effectiveness of remediation depends on the proper selection of the method to be used taking into account the amount and type of contaminants present in the studied area, the geological structure of the area, the location of aquifers and the direction of ground water flow. The aim of this article is to present the in-situ soil remediation methods, which, due to the high effectiveness of removing the most common types of contamination, are applied to the existing infrastructure. The article presents two methods of soil purification on site, the choice of which has been conditioned by the type of soil contamination. The increased content of the surface layer in the area of petroleum substances was neutralized by bioremediation, while in the case of detection of increased content of heavy metals in the form of arsenic at the construction site, the stabilization method designed was used. Due to properly conducted reconnaissance of the area before commencing works, as well as monitoring of the purification process, it was possible to observe the neutralization of pollution occurring in a controlled manner.
\end{abstract}

Key words: remediation, contaminated area, in-situ methods 